\title{
ENERGY ASSESSMENT OF THE PNEUMATIC SIEVE SEPARATOR FOR AGRICULTURAL CROPS
}

Yevhen Mykhailov $^{\mathrm{a}^{*}}$, Natalia Zadosna ${ }^{\mathrm{a}}$, Marina Postnikova ${ }^{\mathrm{b}}$, Ganna Pedchenko ${ }^{\mathrm{c}}$, Vasyl Khmelovskyi ${ }^{d}$, Mariia Bondar ${ }^{\mathrm{e}}$ Aleksey Ionichev ${ }^{\mathrm{f}}$, Michał Kozdęba ${ }^{\mathrm{g}}$, Wioletta Tomaszewska-Górecka ${ }^{\mathrm{h}}$

a Department of Machine Use in Agriculture, Dmytro Motornyi Tavria State Agrotechnological University in Melitopol, e-mail: evgenii19508@gmail.com, ORCID 0000-0001-9906-6699; e-mail: geleantus2017@gmail.com, ORCID 0000-0001-7780-235X

b Department of Electrical Engineering and Electromechanics and Elements of Professor V.V. Ovcharov, Dmytro Motornyi Tavria State Agrotechnological University in Melitopol, e-mail: marina.postnikova@tsatu.edu.ua, ORCID 0000-0002-2025-6199

c Faculty of Economics and Business, Dmytro Motornyi Tavria State Agrotechnological University in Melitopol; e-mail: hanna.pedchenko@tsatu.edu.ua, ORCID 0000-0003-4182-9352

d Department of Livestock Production Mechanization, National University of Life and Environmental Sciences of Ukraine, e-mail: Khmelovskyi@nubip.edu.ua

e Department of Mechanics, Faculty of Construction and Design, National University of Life and Environmental Sciences of Ukraine, e-mail: sergiybondar@ukr.net

f Factor Plus, Israel; e-mail: factor.plus@mail.ru

$\mathrm{g}$ Department of Production Engineering, Logistics and Applied Computer Science, University of Agriculture in Krakow, Balicka 116B, 30-149 Krakow, Poland, e-mail: michal.kozdeba@urk.edu.pl. ORCID 0000-0002-3167-2606

h Eastern European State College of Higher Education in Przemysl, Książąt Lubomirskich 6, 37-700 Przemysl, Poland, e-mail: w.tomaszewska-gorecka@pwsw.eu.

"Corresponding author: e-mail: evgenii19508@gmail.com

\begin{tabular}{l}
\hline ARTICLE INFO \\
\hline Article history: \\
Received: August 2021 \\
Received in the revised form: \\
September 2021 \\
Accepted: October 2021 \\
\hline Keywords: \\
pneumatic separator, \\
seeds of agricultural crops, \\
energy assessment \\
\end{tabular}

ABSTRACT

As a result of energy assessment of a pneumatic sieve separator for agricultural crops it was determined that the specific energy consumption of the experimental pneumatic sieve separator was $0.18 \mathrm{~kW} \cdot \mathrm{t}^{-1}$. It is lower than in case of its domestic and foreign equivalents. For instance, the specific energy consumption of the separator of preliminary grain purification called SPO-50 (Ukraine) is $0.31 \mathrm{~kW} \cdot \mathrm{t}^{-1}$, and that of the machine of preliminary grain purification called MPO-50 (Russia) is 0.38 $\mathrm{kW} \cdot \mathrm{t}^{-1}$. Specific energy consumption of a pneumatic sieve separator is 1.72-2.11 times lower than in case of its domestic and foreign counterparts. 


\section{Introduction}

In the seed production system, there is a multi-stage technology for cleaning, sorting, calibrating seeds after harvesting under conditions of minimal damage (Badretdinov et al., 2019).

Preliminary cleaning of agricultural seeds is one of the most important technological operations of its post-harvest processing in the system of seed preparation (Shymko et al., 2020). The basic material after harvesting is more vulnerable to the influence of various harmful organisms, since it is a mixture of the main crop (Kroulík et al., 2016) extraneous cultivated plants and weeds (Kovalenko et al., 2021).

Therefore, it is an urgent task to intensify preliminary cleaning of seeds of agricultural crops, subject to a decrease in specific energy consumption (Muratov et al., 2020).

The preliminary grain cleaning consists in separation of at least $60 \%$ of the large and airseparable foreign materials from the grain (Wang et al., 2020). This increases their safety in temporary storage. Seed and all food grain are subject to pre-cleaning after harvesting (Jin et al., 2021).

The paper presents analysis of operation of preliminary cleaning means and methods of their investigation. Studies on the procedure of determination of parameters and operating modes of air-sieved separators are presented to a lesser extent (Linenko et al., 2017).

Devices and technological processes of operation of air-sieved separators with a closed air system, providing preliminary cleaning of the grain, are known (Postnikova et al., 2019; Mykhailov et al., 2020; Kharchenko et al., 2019).

A special novelty in the study of air flow parameters of air-sieved separators is provided by a two-stage sedimentation chamber and a suction channel of the fan, which influence validation of the airflow parameters in the fluidization zone of grain materials (GM) and their air separation.

The blowing airflow, which diametrically permeates a cylindrical sieve, plays an important role here (Krzysiak et al., 2020).

The state of the airflow structure and the analysis of factors ensuring the quality of grain material purification form the main task of the study of the air-sieved separators' working process (Konopka at al., 2017).

In Ukraine, the most often used are grain cleaning machines produced in Russia and Ukraine. For a comparative energy assessment of the pneumatic sieve separator, a preliminary grain separator SPO-50 (Ukraine) and a preliminary grain cleaning machine MPO-50 (Russia) were adopted.

A pneumatic sieve separator (PSS) with a closed air system is offered. Estimated specific capacity of the pneumatic sieve separator is 1.5-2.0 times higher than the productivity of existing grain cleaning machines equipped with cylindrical sieves with a horizontal axis of rotation and an external working surface.

The pneumatic sieve separator is simple in design, has a lower metal and energy consumption compared to existing grain pre-cleaning machines, does not have vibrating structural elements, provides high technological and operational reliability, and practically does not injure the processed material (Mykhailov et al., 2020). 


\section{Methodology of research}

The objective of the paperis to conduct an energy assessment of the pneumatic sifter for crops. A pneumatic sieve separator with a closed air system is offered.

The state of the airflow structure and the analysis of factors ensuring the quality of grain material purification form the main task of the study of the air-sieved separators' working process (Nesterenko et al., 2019; Ushakov et al., 2019; Chernyakov et al., 2021).

The proposed separator is equipped with a pneumatic separation sediment chamber with a complex geometric surface connected to the suction channel of a cross-flow fan, which creates a closed pneumatic separation air system, thus improving the process of extracting light impurities, reducing energy consumption for pneumatic separation and does not pollute the environment.

Based on the performed studies, an air-sieved separator with a technological scheme shown in Fig. 1 (Zadosnaya, 2020) is suggested.

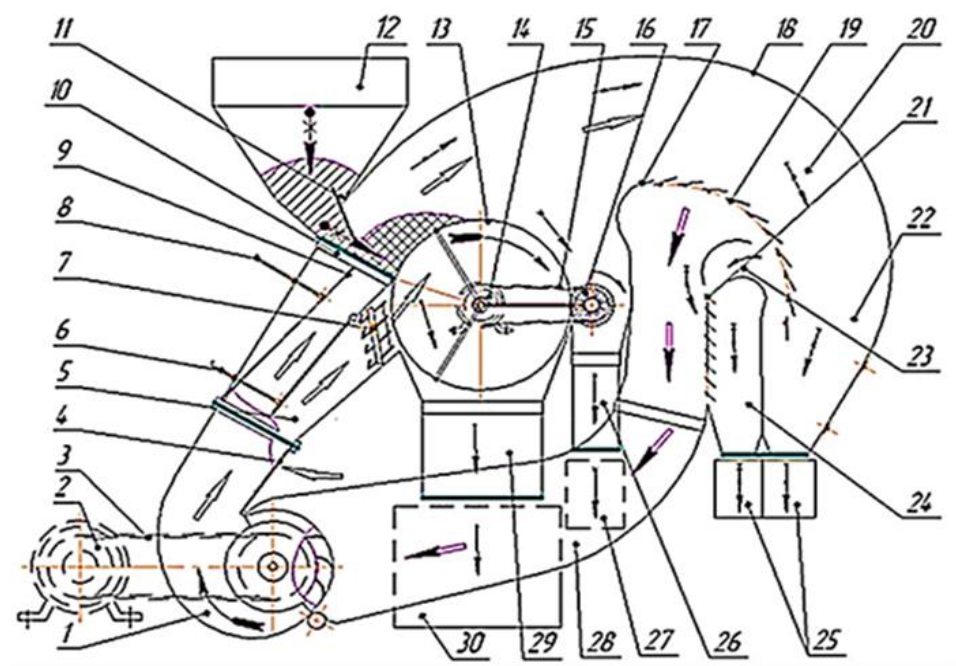

Figure 1. Technological scheme of an air-sieved separator

1 - diametric fan; 2 - direct current motor; 3 - fan drive; 4 - louvers for additional airflow inlet in the fan; 5 - air distributor; 6 - middle movable wall control lever; 7 - air distributor louvers; 8 - rear movable wall control lever; 9 - extension of the rear movable wall; 10 - tray-intensifier; 11 - charging hopper flap; 12 - hopper; 13 - cylindrical sieve; 14 -reducing gear motor; 15 - brush cleaner drive; 16 - brush cleaner; 17 - airflow cutter; 18 - shell of the air channel of a sedimentation chamber; 19 - working surface of the 1st stage cleaning louver; 20 - air channel of the 1st stage cleaning; 21 - surface of the 2 nd stage cleaning louver; 22 - sedimentation chamber of the 1st stage of purification; 23 - input channel of the 2nd stage of purification; 24 - sedimentation chamber of the 2nd stage of purification; 25 - hopper for impurities of the 1st and 2nd stage of the sedimentation chamber; 26 - the channel and the valve for the large impurities outlet; 27 - hopper of large impurities; 28 - the suction channel of the fan; 29 - channel and valve of the purified grain material; 30 - hopper of purified grain material. 


\section{Research results}

According to the creative cooperation agreement between Tavria State Agrotechnological University and Motor Sich OJSC (Gulaypole) subsidiary Gulaypole Mechanical Plant, an experimental pneumatic separator has been produced (Fig. 2 and 3)

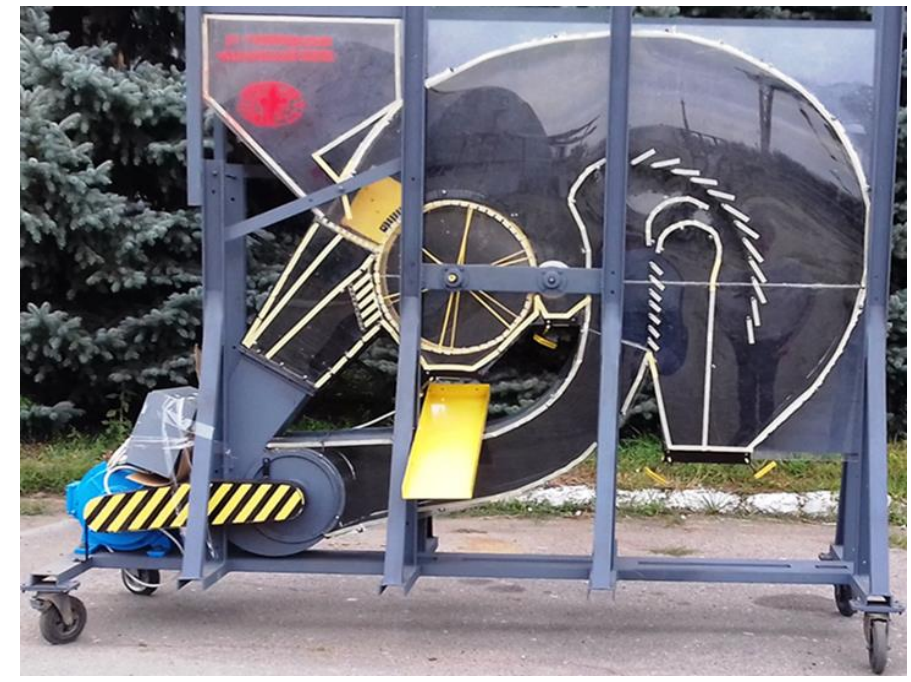

Figure. 2. Pneumatic sieve separator for preliminary cleaning of seeds of agricultural crops

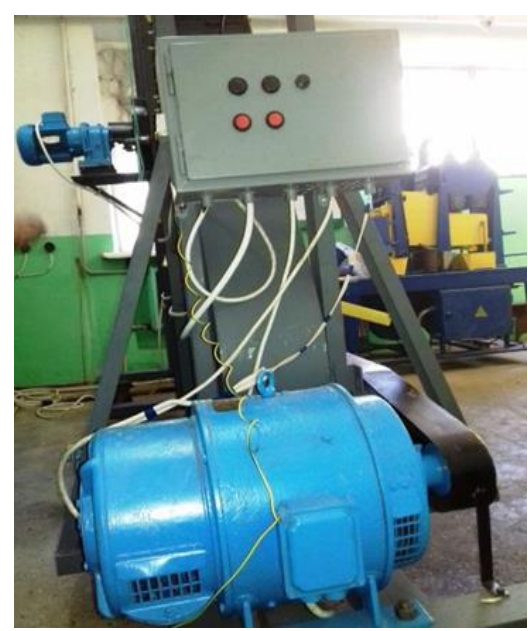

a

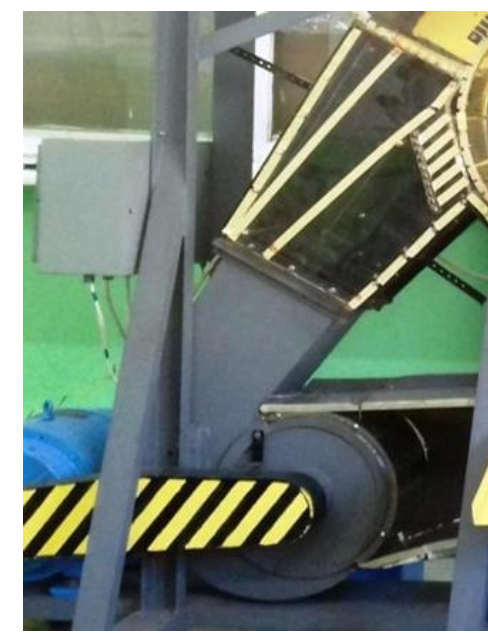

b

Figure 3. Operational parts of the pneumatic sieve separator

$\mathrm{a}-$ control panel with D.C. motor; $\mathrm{b}$ - drive of the diametric fan. 
The main parameters and design dimensions are defined based on the results of theoretical studies and previous search experiments (Mykhailov et al., 2020).

To calculate indicators of the specific energy consumption of the experimental pneumatic sieve separator, the generally accepted method of determination of the energy consumption per unit of processed material was applied (Tishchenko and Kharchenko, 2013)

Since energy consumption is one of the most important characteristics when selecting a separator, the research was carried out to measure the power consumed by the separator.

It is reasonable to divide power consumed by the separator into the following components - power consumption when there is no grain material in the separator (idle running);

- power consumption of the separator's operating mode (Shaker, 2015).

Determination of power consumption makes it possible to determine the energy consumption for experimental PSS operation (Aliev et al., 2018).

We measured voltage and current at PSS's idle running and at its operating mode. The calculation was carried out with the help of the formula (Postnikova et al., 2019):

where:

$$
P=3 \cdot I_{c} \cdot U_{v} \cdot \cos \varphi
$$

$I_{c} \quad-$ phase current,

A; $U_{v} \quad-$ phase voltage,

$\mathrm{V} ; \varphi \quad$ - phase shift angle between current and voltage.

To calculate the experimental PSS specific energy consumption, we used the standard practice of determination of the energy consumption per unit of processed material.

To determine the cost of electricity for the fan drive, experimental studies were carried out, the results of which are shown in Table 1. The determination of indicators Ip, Up and the calculation of the value was carried out at various values of the fan rotor speed $n$.

Table 1.

Indicators of energy consumption for the fan drive

\begin{tabular}{crlll}
\hline Number & $N(\mathrm{rpm})$ & $I_{p}(\mathrm{~A})$ & $U_{p},(\mathrm{~V})$ & $P(\mathrm{~kW})$ \\
\hline 1 & 425 & 1.6 & 70 & 0.164 \\
2 & 470 & 1.8 & 80 & 0.212 \\
3 & 510 & 1.9 & 90 & 0.251 \\
4 & 560 & 2.2 & 100 & 0.323 \\
5 & 620 & 2.3 & 110 & 0.372 \\
6 & 640 & 2.5 & 120 & 0.441 \\
7 & 680 & 2.7 & 130 & 0.516 \\
8 & 740 & 3.2 & 140 & 0.659 \\
9 & 780 & 3.4 & 150 & 0.750 \\
10 & 840 & 3.8 & 160 & 0.894 \\
11 & 890 & 4.0 & 170 & 0.944 \\
12 & 940 & 4.5 & 180 & 1.125 \\
13 & 970 & 4.8 & 190 & 1.266 \\
14 & 1020 & 5.1 & 200 & 1.417 \\
15 & 1060 & 5.5 & 210 & 1.604 \\
16 & 1080 & 5.8 & 220 & 1.770 \\
17 & 1140 & 6.5 & 230 & 2.076 \\
\hline
\end{tabular}


In the range of measurement $\mathrm{n}$ from 425 to $1140 \mathrm{rpm}$ electricity costs $P$ vary from 0.2 to $2.1 \mathrm{~kW}$. When cleaning seeds that have a hovering speed of 3.0 to $6.5 \mathrm{~m} \cdot \mathrm{s}^{-1}$ (e.g., sunflower seeds), at values of $n-425-650 \mathrm{rpm}$, the value of $P$ does not exceed $0.42 \mathrm{~kW}$.

In the measurement range of $\mathrm{n}$ from 900 to $1175 \mathrm{rpm}$ when cleaning seeds, which have a hovering speed of 8.0 to $13.0 \mathrm{~m} \cdot \mathrm{s}^{-1}$ (e.g., wheat, corn), the values of $P$ can reach $2.1 \mathrm{~kW}$.

The conducted research on the cleaning of sunflower seeds made it possible to obtain the dependence of the unit consumption of electricity $\mathrm{N}_{n}$ of the PSS on its specific productivity q, taking into account the change in the length of the cylindrical sieve in decimeters. (Fig. 4)

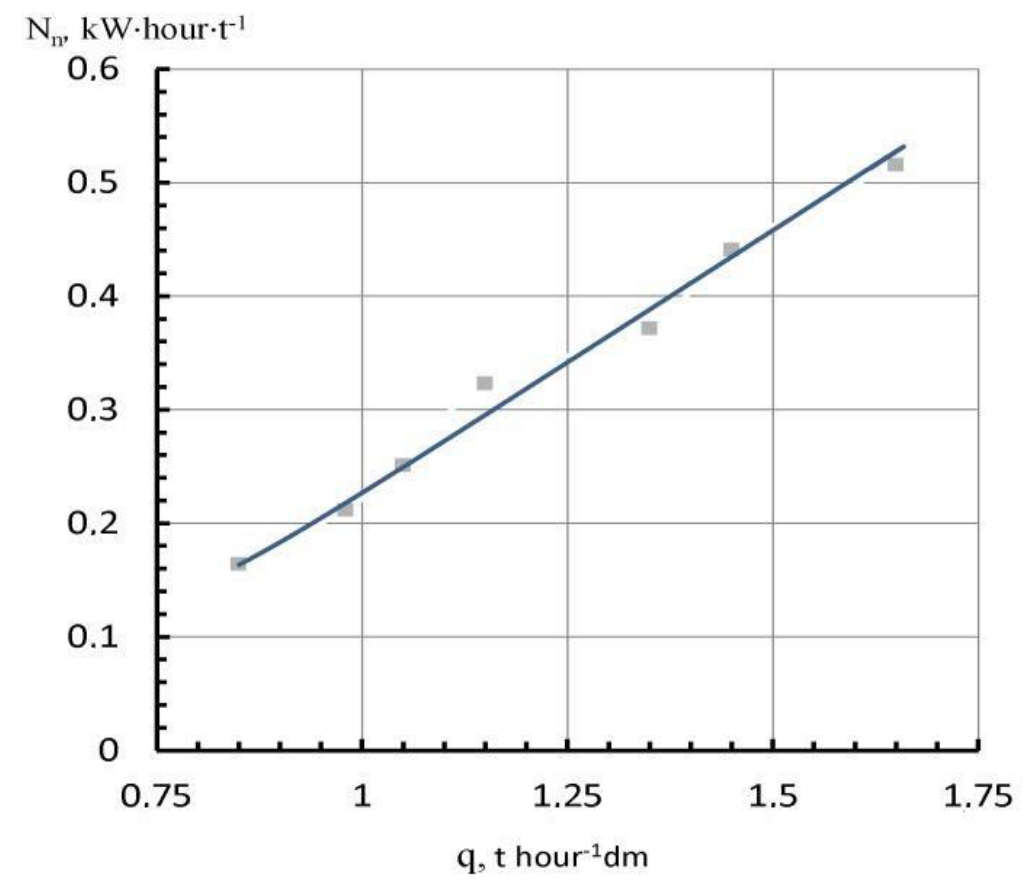

Figure 4. Dependence of the unit costs of electricity $N_{n}$ of the PSS on its specific productivity $q$

So, with an increase in $\mathrm{q}$ from 0.85 to $1.75 \mathrm{t}^{-1}$, the value of the specific energy consumption per ton of treated seeds $\mathrm{N}_{\mathrm{n}}$ is within the range of $0.16-0.52 \mathrm{~kW} \cdot \mathrm{t}^{-1}$.

Taking into account the agrotechnical requirements for permissible losses and the effect of cleaning seeds, the specific energy consumption is $0.16-0.18 \mathrm{~kW} \cdot \mathrm{t}^{-1}$.

The indicator of the specific energy consumption of the experimental pneumatic sieve separator, in contrast to the existing technical equivalents, is lower and amounts to 0.18 $\mathrm{kW} \cdot \mathrm{t}^{-1}$ (Table 2). 
Energy assessment...

Table 2.

Rates of the experimental PSS's specific energy consumption as distinct from existing technical counterparts

\begin{tabular}{lccc}
\hline $\begin{array}{l}\text { Technical } \\
\text { counterparts }\end{array}$ & $\begin{array}{c}\text { Pneumatic sieve } \\
\text { separator }\end{array}$ & $\begin{array}{c}\text { Separator of prelimi- } \\
\text { nary grain purification } \\
\text { SPO-50 (Ukraine) }\end{array}$ & $\begin{array}{c}\text { Machine of preliminary } \\
\text { grain purification } \\
\text { MPO-50 (Russia) }\end{array}$ \\
\hline $\begin{array}{l}\text { Specific energy con- } \\
\text { sumption of technical } \\
\text { means, } \mathrm{kW} \cdot \mathrm{t}^{-1}\end{array}$ & 0.18 & 0.31 & 0.38 \\
$\begin{array}{l}\text { PSS's energy } \\
\text { efficiency coefficient } \\
\text { compared to its coun- } \\
\text { terparts }\end{array}$ & 1.0 & 1.72 & 2.11 \\
\hline
\end{tabular}

Estimated specific capacity of the pneumatic sieve separator is 1.5-2.0 times higher than the productivity of existing grain cleaning machines equipped with cylindrical sieves with a horizontal axis of rotation and an external working surface.

The pneumatic sieve separator is simple in design, has a lower metal and energy consumption compared to the existing grain pre-cleaning machines, does not have vibrating structural elements, provides high technological and operational reliability, and practically does not injure the processed material.

\section{Conclusions}

1. As a result of energy assessment of the pneumatic sieve separator for agricultural crops it was determined that the specific energy consumption of the experimental pneumatic sieve separator was $0.18 \mathrm{~kW} \cdot$ year $\cdot \mathrm{t}^{-1}$. It is lower than in its domestic and foreign counterparts. For instance, the specific energy consumption of the separator of preliminary grain purification called SPO-50 (Ukraine) is $0.31 \mathrm{~kW} \cdot$ year $\cdot \mathrm{t}^{-1}$, and that of the machine of preliminary grain purification called MPO-50 (Russia) is $0.38 \mathrm{~kW} \cdot$ year $\cdot \mathrm{t}^{-1}$.

2. According to the obtained results, specific energy consumption of a pneumatic sieve separator is 1.72-2.11 times lower than its domestic and foreign counterparts have.

\section{References}

Aipov, R., Linenko, A., Badretdinov, I., Tuktarov, M., Akchurin, S. (2020). Research of the work of the sieve mill of a grain-cleaning machine with a linear asynchronous drive. Mathematical Biosciences and Engineering, 17(4), 4348-4363.

Aliev, E., Bandura, V., Pryshliak, V., Yaropud, V., Trukhanska, O. (2018). Modeling of mechanical and technological processes of the agricultural industry. INMATEH Agricultural Engineering, 54(1), 95-104.

Babić, L., Radojćin, M., Pavkov, I., Babić, M., Turan, J., Zoranović, M., Stanišić, S. (2013). Physical properties and compression loading behaviour of corn seed. International Agrophysics, 27(2), 119-126. 
Badretdinov, I., Mudarisov, S., Tuktarov, M., Dick, E., Arslanbekova, S. (2019). Mathematical modeling of the grain material separation in the pneumatic system of the grain-cleaning machine. Journal of Applied Engineering Science, 17(4), 529-534.

Bilgin, B., Liang, J., Terzic, M.V., Dong, J., Rodriguez, R., Trickett, E., Emadi, A. (2019). Modeling and Analysis of Electric Motors: State-of-the-Art Review. IEEE Transactions on Transportation Electrification, 5(3), 602-617.

Boac, J.M., Ambrose, R.P.K., Casada, M.E., Maghirang, R.G., Maier, D.E. (2014). Applications of Discrete Element Method in Modeling of Grain Postharvest Operations. Food Engineering Reviews, 6(4), 128-149.

Bredykhin, V., Gurskyi, P., Alfyorov, O., Bredykhina, K., Pak, A. (2021). Improving the Mechanicalmathematical Model of Grain Mass Separation in A Fluidized Bed. Eastern-European Journal of Enterprise Technologies, 3, 79-86.

Chernyakov, A.V., Koval, V.S., Yatsunov, A.N., Begunov, M.A., Shevchenko, A.P. (2021). Research of a conical pneumatic grain separator with a device for forced light fraction removal. IOP Conference Series: Earth and Environmental Science, 659(1), 0120412020.

Choszcz, D.J., Reszczyński, P.S., Kolankowska, E., Konopka, S., Lipiński, A. (2020). The Effect of Selected Factors on Separation Efficiency in a Pneumatic Conical Separator. Sustainability, 12, 3051.

Cieślik, S. (2021) Mathematical modeling of the dynamics of linear electrical systems with parallel calculations. Energies, 14(102), 2930

Hidy, G.M. (2003). Aerosols. In Encyclopedia of Physical Science and Technology (Third Edition). Academic Press, Amsterdam, ISBN 9780122274107.

Ivanyshyn, V., Yermakov, S., Ishchenko, T., Mudryk, K., Hutsol, T. (2020). Calculation algorithm for the dynamic coefficient of vibro-viscosity and other properties of energy willow cuttings movement in terms of their unloading from the tanker. E3S Web of Conferences, 154, 04005 https://10.1051/e3sconf/202015404005

Jin, H., Hu, S., Xie, B., Yan, Y., Yang, M., Zhou, F. (2021). Experimental optimization for cleaning parameters and field application of cartridge filter in bulk grain loading. Powder Technology, 378 , 421-429.

Josephine, B., Ambrose, R., Mark, C., Ronaldo, M., Dirk, M. (2014). Applications of discrete element method in modeling of grain postharvest operations. Food Engineering Reviews, 6(4), 128-149.

Kharchenko, S., Kovalyshyn, S., Zavgorodniy, A., Kharchenko, F., Mikhaylov, Ye., (2019) Effective sifting of flat seeds through sieve. Eastern-European Journal of Enterprise Technologies, 58(2), 17-26.

Konopka, S., Choszcz, D., Markowski, P. (2017). Optimization of the Separation Parameters and Indicators of Separation Efficiency of Buckwheat Seeds. Sustainability, 9, 2134.

Kovalenko, N., Kovalenko, V., Hutsol, T., Ievstafiieva, Y., Polishchuk, A. (2021). Economic Efficiency and Internal Competitive Advantages of Grain Production in the Central Region of Ukraine. Agricultural Engineering, 25(1), 51-62.

Kroulík M., Hůla, J. Rybka, A. Honzík I. (2016). Pneumatic conveying characteristics of seeds in a vertical ascending airstream. Research in Agricultural Engineering, 62(2), 56-63.

Krzysiak, Z., Samociuk, W., Zarajczyk, J., Beer-Lech K., Bartnik, G., Kaliniewicz, Z., Dziki, D. (2020). Effect of sieve unit inclination angle in a rotary cleaning device for barley grain. Transactions of the ASABET, 63(3), 609-618.

Linenko, A., Tuktarov, M., Aipov, R., Baynazarov, V. (2017). Analysis of pulsed operating mode of linear induction drive of grain cleaning machine. Proceedings of the International Conference Actual Issues of Mechanical Engineering, 133, 420-424.

Mudarisov, S., Khasanov, E., Rakhimov, Z., Gabitov, I., Badretdinov, I., Farchutdinov, I., Gallyamov, F., Davletshin, M., Aipov, R., Jarullin, R. (2017). Specifying Two-Phase Flow in Modeling Pneumatic Systems Performance of Farm Machines. Journal of Mechanical Engineering Research and Developments, 40(4), 706-715. 
Muratov, D., Kravchenko, E., Sukhoveeva, A., Andreeva, O. (2020). Innovative study on pneumatic separation of grain heap and economic feasibility of design versions. E3S Web of Conferences: 8th Innovative Technologies in Science and Education, ITSE 2020, 19 August 2020 - 30 August 2020, $210,05010$.

Mykhailov, Ye., Golebiewski, J., Kiurchev, S., Hutsol, T., Kolodii, O., Nurek, T., Glowacki, Sz., Zadosna, N., Verkholantseva, V., Palianychka, N., Kucher, O. (2020). Economic and technical efficiency of sunflower seed treatment. Warsaw University of Life Sciences Press, Warsaw. ISBN 97883-7583-934-0.

Nesterenko, A., Leshchenko, S., Vasylkovskyi, O., Petrenko, D. (2019). Justification of Technological Parameters of the Grain Separator. Design, Production and Exploitation of Agricultural Machines, 49, 67-72.

Panasiewicz, M., Zawislak, K., Kusinska, E., Sobczak, P. (2008). Purification and separation of loose material in pneumatic system with vertical air stream. TEKA Kom. Mot. Energ. Roln, 8, 171-176.

Postnikova, M., Mikhailov, E., Nesterchuk, D., Rechina, O. (2019). Energy saving in the technological process of the grain grinding W.(eds.) Euro-Par Springer, Heidelberg, LNCS, 2 , 395-403.

Shaker, A. (2015). Theory of Agricultural Machine, Algadeer Co. for Printing and Publishing. Basrah, Iraq, p. 155.

Shymko, L.S., Voinash, S.A., Andronov, A.V. (2020). Mathematical modeling of grain mictures in optimatization tasks of the dump bunker's kinematic parameters. IOP Conference Series: Earth and Environmental Sciencethis, 548(6), 062055.

Tishchenko, L., Kharchenko, S. (2013). Application of methods of continuous environments mechanics for the description of grain mixes movement on vibro sieves, MOTROL. Commission of Motorization and Energetics in Agriculture, 15, 94-99.

Tryhuba, A., Hutsol, T., Glowacki, S., Tryhuba, I., Tabor, S., Kwasniewski, D., Sorokin, D., Yermakov S. (2021). Forecasting Quantitative Risk Indicators of Investors in Projects of Biohydrogen Production from Agricultural Raw Materials. Processes. 9(2):258. https://doi.org/10.3390/pr9020258

Ushakov, Y., Shakhov, V., Asmankin, E., Naumov, D. (2019). Theoretical study results of product flow management process in hammer-type shredder working chamber. Engineering for Rural Development, 18, 185-191.

Vedmedeva, K., Soroka, A. (2015). Influence of some mutant genes on certain agronomically important traits in sunflower. Helia, 2, 21-22.

Wang, GY., Wu, WF., Qiao, FX., Fu, DP., Liu, Z., Han, F. (2020). Research on an electric energysaving grain drying system with internal circulation of the drying medium. Journal of Food Process Engineering, 43(9), e13476.

Yang, X., Shen, Y. (2015). Runge-Kutta Method for Solving Uncertain Differential Equations. Journal of Uncertainty Analysis and Applications, 3, 17.

Yermakov, S., Hutsol, T., Rozkosz, A., Glowacki, S., Slobodian, S. (2021). Evaluation Of Effective Parameters Of Biomass Heat Treatment In Processing For Solid Fuel. Engineering For Rural Development. https://doi.org/10.22616/ERDev.2021.20.TF241

Zadosnaya, N. (2020). Justification of the parameters and operating modes of the louvered air distributor of the pneumatic sieve separator of sunflower oil raw materials. Ph.D. thesis., 260. 
Yevhen Mykhailov et al.

\section{OCENA ENERGETYCZNA PRACY PRZESIEWACZA PNEUMATYCZNEGO DO PLODÓW ROLNYCH}

Streszczenie. W wyniku oceny energetycznej pneumatycznego separatora sitowego dla płodów rolnych ustalono, że jednostkowe zużycie energii eksperymentalnego pneumatycznego separatora sitowego wynosi $0,18 \mathrm{~kW} \cdot \mathrm{t}^{-1}$. Jest ono niższe niż w przypadku jego krajowych i zagranicznych odpowiedników. Na przykład, jednostkowe zużycie energii separatora do wstępnego oczyszczania ziarna o nazwie SPO-50 (Ukraina) wynosi $0,31 \mathrm{~kW} \cdot \mathrm{t}^{-1}$, a urządzenia do wstępnego oczyszczania ziarna o nazwie MPO-50 (Rosja) - 0,38 $\mathrm{kW} \cdot \mathrm{t}^{-1}$. Jednostkowe zużycie energii przez pneumatyczny separator sitowy jest 1.72-2.11 razy niższe niż jego krajowych i zagranicznych odpowiedników.

Słowa kluczowe: separator pneumatyczny, nasiona upraw rolnych, ocena energetyczna 